\title{
Üniversite Öğrencilerinin Sahip Olduğu Değerler Akılcı Olmayan İnançlar ve Sosyal Görünüş Kaygısı Arasındaki Yordayıcı İlişkiler
}

\author{
DOI: $10.26466 /$ opus.547765 \\ * \\ Bülent Dilmaç* - Ömer Yücesoy** \\ * Prof. Dr., Necmettin Erbakan Üni., Ahmet Keleşoğlu Eğitim Fak. Meram / Konya/ Türkiye \\ E-Posta: bulentdilmac@gmail.com \\ ORCID: 0000-0001-5753-9355 \\ ** Psik. Dnş., Yusuf Özvtan Ortaokulu, İstanbul/Türkiye \\ E-Posta: pdromeryucesoy@gmail.com \\ ORCID: 0000-0002-8804-8038
}

Öz

Bu araştırmanın amacl, üniversite öğrencilerinde değerler, akılcı olmayan inançlar ve sosyal görünüş kaygısı değişkenleri arasındaki yordayıcı ilişkinin araştıılması Yapılan araştırmada değerler, akılcı olmayan inançlar ve sosyal görünüş kaygısı değişkenleri arasındaki ilişkinin sınanması amacıyla yapısal eşitlik modellemesi analizi yapılmıştır. Yapısal eşitlik modellemesi olarak belirlenmiştir. analizi AMOS 19 Programı ile gerçekleştirilmiştir. Yapılan araştırmada gerekli verilerin toplanması için, Kişisel Bilgi Formu, üniversite öğrencilerinin sahip oldukları değerleri belirlemek için "Değerler Ölçeği", akılcı olmayan inançların belirlemek için "Akılcı Olmayan İnançlar Ölçeği" ve sosyal görünüş kaygılarını belirlemek için "Sosyal Görünüş Kaygısı Ölçeği" kullanılmıştır. Toplanan verilerin yüzde ve frekans hesapları SPSS 18 paket programı ile oluşturulmuştur.Ölçekler, 2017-2018 eğitim öğretim döneminde İstanbul'da çeşitli üniversitelerde öğrenim gören üniversite öğrencilerinden oluşmaktadır. 544 katılımoının 217'si erkek 327'si kız katılımcıdır. Araştırmadan elde edilen analiz sonuçlarına göre, değerler ile akılcı olmayan inançlar arasında negatif yönlü doğrusal ilişki ortaya çıkmıştır. Bununla beraber değerler değişkeni ve bir diğger değiş̧ken olan sosyal görünüş kaygısı değişkeni arasında negatif yönlü doğrusal bir ilişkinin olduğu saptanmıştır.Son olarak üniversite öğrencilerinin akılcı olmayan inançları ve sosyal görünüş kaygısı değişkenleri arasındaki ilişki gözlemlendiğinde, pozitif yönlü doğrusal bir ilişkinin ortaya çıktığı görülmüştür.

Anahtar Kelimeler: Değerler, Akılcı Olmayan İnançlar, Sosyal Görünüş Kaygısı 


\title{
The Precurser Relations Among The Values Which The University Students Have Their Irrational Belief and Their Social Apperance Anxiety
}

*

\begin{abstract}
The aim of the research is to study the precurser relation among the values which the university students have, their irrational beliefs and their social apperance anxiety. In the research, structural equation modeling analysis is carried out with the purpose of testing the precurser relation among the values, irrational beliefs and social appearance anxiety. It is carried out with AMOS 19 program, we were used the personal information form, The Value Scale, determining yhe values witch the unniversity students have, the irrational beliefs scale determining their irrational beliefs, the social apperance anxiety scale determing their social apperance anxiety.Percentage and freqvency calculation of collecded data were olso perfermed with the SPSS 18 packed program. The scales are composed of university students from various universities in Istanbul during the 2017-2018 education period. Of the 544 participants, 217 are male and 327 are female par-ticipants. According to the findings as a result of the analyzes, it determined that there is a negative relationship between the values and irrational beliefs. It has also determined that there is a negative relationship between the values and the social apperance anxienty. Finally, when the precursor relations of the university students irrational beliefs and the social apperance anxiety have studied, it has determined that there is a positive relationship between them.
\end{abstract}

Keywords: Values, Irrational Beliefs, Social Appearance Anxiety 


\section{Giriş}

Günlük yaşamda görülen hızlı değişmeler ışığında gençler, değişen toplum düzeninde farklı rol beklentilerine giderek, psikolojik bir kimlik arayışında kalacak ve kendi yaşı gereği değer yargıları hızla değişim gösteren gençlerin, yaşamını sürdürdükleri toplumun değerlerinin de değişmesi karşısında zorlandıkları görülmektedir (Hökelekli, 2006). Toplumun hızlı gelişimi ve yaşamını sürdürdükleri geçiş dönemi itibariyle gençler birçok problemlerle karşılaşmaktadırlar ve bu problemlerin belli başlıları uzaklaşma, kimlik bunalımları, değerlerdeki değişimler, sosyal psikolojik birçok problemler ve endişeler olarak görülebilir (Aydım, 2003). Gençlik dönemin de kimliklerin ve kişiliğin ortaya çıkmasında, evrensel görüş ve sorunların çözümünde değerlerin çok önemli bir etkisi olmakta ve geri dönüşümlü olarak gençlik de değerlerin algılanıp toplumda yeniden şekil kazanmasında önemli bir etkiye sahip olmaktadır (Aydın, 2003).

Pozitivizmin bazı etkileri ve bunlara bağlı olumsuz tavırlarından dolayı çok uzun zaman boyunca sosyal bilimlerde değerler kavramı araştırılmaya değer görülmemiş ve bu tür araştırmalar bilim ile alakalı görülmemiştir (Akyüz, 2014). Fakat değerler, insani yaşamda davranışları, tutumları ve birçok olguyu etkilemekte ve her insani durumda bir veya birden fazla değer ve yönlendiricileri bulunmaktadır (Aydın, 2003). Bu bağlamda çeşitli alanda araştırma yapan sosyologlar, sosyal psikologlar, antropologlar ve psikologlar değerlerle ilgili çalışmalar sürdürdükleri görülmektedir (Kuşdil ve Kağıtçıbaşı, 2000). Değer kavramı bireylerin düşünce duygu ve tutumlarıyla yakından ilgili olmakla birlikte sosyal alanlarda yapılan araştırmaların birçoğunda insan davranışlarını açıklamada başlıca bir öneme sahip olduğunu ifade etmektedir (Kuşdil ve Kağıtçıbaşı, 2000).

Değer kavramı ilk kez karşımıza sosyal bilimcilere katkı olarakZnanieckiadlı kişiden kazandırılmış ve Latincede karşıllı̆̆ "kıymetli olmak" yada "güçlü olmak " anlamını ifade eden "valere" kökünden gelmektedir (Bilgin, 1995). Schwartz değeri bireylerin kendileri de değerlendirmek üzere bütün bireyleri ve olguları incelemek ve eylemleri seçmek ve uygunlaştırmak için kullandıkları yapılardır (Schwartz, 1992). Güngör (2010) değerleri tanımlarken “bir şeyin arzu edilebilir yada 
edilmez olduğu hakkındaki inançlar" olarak ifade etmektedir. Tüm bu tanımlamalardan sonra Ulusoy ve Dilmaç (2016, s.16)'a göre değerler üzerine yapılan tanımlamalardan yola çıkarak değer kavramını : "İnsanı insan yapan özelliklere sahip olan ve insanı diğer canlılardan ayıran temel özellikleri içinde barındıran ve insanların davranışlarına yön veren inançlar bütünü' olarak ele alıp tanımlamasını yapmıştır.

Değerler konusunda çalışma yapmanın başlıca amaçlarından biri, kişilerin sahip olduğu değer yargılarının yönelimlerini tespit etmek ve kişilerin tutum, edim vesosyaltecrübe ve görevleriyle alakalıyönelimlerini belirlemektir (Mehmedoğlu, 2006). Ayrıca değerler, bireylerin sergilediklerihâl ve edimlerinortaya çıkmasında ve manipüle etmesinde büyük birfonksiyona sahiptir (Kulaksızoğlu ve Dilmaç, 2000).

$\mathrm{Bu}$ bağlamda bireylerin yaşadığı problemlerin ve sorunların çözümünde değerlerin etkisinin büyük olduğu düşünülmektedir. Davranışlarımızı inançlar ve değerler sistemimizin oluşturduğunu düşünürsek böylece davranışlarımız ve inanç sistemlerimiz değerleri etkilediği söylenebilir. Yaşadığımız problemlerin çözümünde Akılcı Duygusal Davranışçı Terapinin bu problemleri çözümünde büyük bir etkiye sahip olduğu beklenebilir.

Üniversite öğrencilerinin gelişim özellikleri göz önüne alındığında oluşturdukları kimlikler, kendi değerini bulma, anne ve babadan bağımsız olarak hareket etme, diğer insanlarla yakın ilişkiler kurma başkalarının sorunlarına çözüm üretmek ve diğer insanların duygularını kavramaya çalışmak, yetişkinlik rolünü benimsemek gibi durumlar birey için oldukça önemli bir durumdur (Yurtal,1999). Üniversite de öğrenim gören öğrencilerin bu dönemde yaşadıkları hızlı değişimlere paralel olarak kullanılan önleyici ve korucu ruh sağlığı yöntemleri de sürekli gelişim göstermekte ve son zamanlarda yapılan çalışmalar gözlemlendiğinde, bilişsel alanda yapılan psikolojik yardımın ve bilişsel davranışçı terapiye olan ilgi ve isteğin arttığı görülmektedir (Yurtal,1999).

Bilişsel davranışçı yaklaşımın içeriğine sahip olan Bilişsel terapinin temel kavramları bilişsel çarpıtmalar ve işlevsel olmayan düşüncelerdir. Aynı yaklaşımı ele alan ve Ellis ile geliştirilen Akılcı Duygusal Davranışı̧ı Terapi' de irrasyonel inançları ele alınmaktadır (Erdem ve Bilge, 2008). ADTT' ye göre psikolojik sağlığı etkileyen nedenler mantıkdışı yani akılcı olmayan inanç ve düşüncelerimizdir (Ellis,1995). Ellis, bizi etkileyen ve 
psikolojik sağlığımızı olumsuz etkileyen bu akılcı olmayan inançlarımızın kendimiz hakkında geliştirdiğimiz bazı sayıltılarda görülmekte ve bu sayıltılar birçok duygusal olumsuzluklara yol açtığı söylenebilmektedir (Doğan, 1995).

Akılcı Duygusal Davranışçı Terapi (ADDT), bireylerin hem akılcı hem de akılcı olmayan yani mantıkdışı düşünme şekli ile doğduklarını düşünmektedirler (Corey, 2008). Bireyler hem dürüstlük, hoşgörü, sevme gibi olumlu ilişkiler yanında hoşgörüsüzlük, adaletsizlik düşmanlık gibi olumsuz düşüncelere de yatkınlıkları bulunmaktadır. Akılcı duygusal davranışçı terapiye göre mantıkdışı (akılcı olmayan) düşünceler çocukluk döneminde kendileri için önemli bireylerden öğrenmektedirler veya kendi kendilerine de sahip olabilmektedirler ve psikolojik rahatsızlıkların temelinde bireyin akılcı olmayan düşüncelerinin olmasıdır (Corey, 2008).Bu şekilde oluşan akılcı olmayan inanç sistemi çocukluk yıllarında başlayıp hayat boyu devam eden bilişsel çarpıtmlarla desteklenir (Savaşır ve Batur, 1996).

Üniversitede öğrenim gören öğrencilerin dönemi, kişilikleri ve bireysel farklılıklara göre ileri ergenlik dönemi yada genç yetişkinlik dönemi olarak ele alınabilmekte bu sebeple ileri ergenlik ve genç yetişkinlik dönemlerinin özelliklerini ele aldığımızda Arnett (2006) ' e göre gençlik dönemi özellikleri iş ve aşk konularında kimlik belirlenmesinin yaşandığı ve bireyin kendine odaklandığı, hayatta birçok fırsatla karşılaştığı bir dönemdir. Kişinin oluşturduğu kimlik arayışı ve gencin yaşadığı değişkenlik bu dönemin geçiş dönemi olmasına katkıda bulunur (Atak ve Çok, 2010). Birey bu dönemde özellikle insanlarla kurduğu ilişkilerde ve bireyin kendisinde olan değişimlerde özellikle görünüşü ve yakın ilişkileri konusunda temel bazı durumları ortaya çıkarmaktadır (Arnett, 2006). Yakın ilişkilerin yoğun olduğu bu dönem bireyin görünüşü ile ilgili tutum ve davranışları diğer kişilerle olan iletişimini ve ilişkisini etkilemektedir (Cash, Thériault ve Annis, 2004; McKinley ve Randa, 2005).

Bireyler diğer kişiler tarafından iyi bir izlenim oluşturmayı ister ve bu iyi izlenim oluşturamayacaklarını algıladıklarında üzüntülü ve gergin hissetmeleri sosyal görünüş kaygısı olarak açıklanmaktadır (Leary ve Kowalski, 1995).Hart ve diğerleri (2008) tarafından yapılan vücut şekli de ele alınıp bireyin genel görünüşünün olumsuz gözlemlenmesine yönelik kişide oluşan kaygıyı ölçmek için Sosyal Görünüş Kaygısını geliştirmiş ve 
araştırma sonucuna göre sosyal görünüş kaygısının sosyal kaygı ile oldukça yüksek şekilde ilişkili olduğu tespit edilmiş ve sosyal görünüş kaygısı daha geniş bir alan olan sosyal kaygının içerisinde olduğu düşünülmektedir.

Sosyal görünüş kaygısı ise bireyin kendi vücuduna yönelik olumsuz düşünceleri şeklinde açıklanabilmektedir (Doğan, 2010). Ayrıca Doğan (2010)' a göre sosyal görünüş kaygısının özünde beden imajı bulunmaktadır. Sosyal görünüş kaygısı, farklı problemlerle beraber görülen ve gündelik yaşamda kişiyi olumsuz etkileyen ve insanın fiziksel görünümüyle ilgili hissettiği üzüntüyü ve bireyin diğer insanlar tarafından değerlendirilmek ile ilgili sezdiği kaygıyı içermektedir (Doğan, 2010).

Hart ve arkadaşları (2008)' e göre sosyal görünüş kaygısı, bireyin fiziksel görünüşünden çok bireyin ten rengi, yüz şekli, göz rengi gibi daha geniş özellikleri içeren bir kaygı olarak tanımlamaktadır. Hart, Leary ve Rejeski (1989)' ise sosyal görünüş kaygısını bireylerin fiziksel görünüşlerinin diğer kişiler tarafından incelenmesiyle yaşadıkları üzüntü ve kaygı olarak açıklamaktadır.

$\mathrm{Bu}$ araştırmanın temel amacı, üniversite öğrencilerinin sahip oldukları değerler, akılcı olmayan inançlar ve sosyal görünüş kaygısı arasındaki yordayıcı ilişkiyi ortaya çıkarmaktır. Bu amaç doğrultusunda aşağıdaki sorulara cevap bulmaya çalışılmıştır.

1. Üniversite öğrencilerinin sahip oldukları değerler akılcı olmayan inançlarını anlamlı düzeyde açıklamakta mıdır?

2. Üniversite öğrencilerinin sahip oldukları değerler sosyal görünüş kaygılarını anlamlı düzeyde açıklamakta mıdır?

3. Üniversite öğrencilerinin akılcı olmayan inançları ve sosyal görünüş kaygıları birbirini yordamakta mıdır?

Ülkemizde değerler, akılcı olmayan inançlarla ilgili bir çok araştırmaya rastlanmışken literatürde üniversite öğrencilerinin sahip oldukları değerler, akılcı olmayan inançları ve sosyal görünüş kaygısı açısından ilişkilerini açıklamaya yönelik bir çalışmaya rastlanılmamıştır. Yapılan bu araştırmanın bu anlamda literatüre katkı sağlayacağı ayrıca bundan sonra yapılacak çalışmalar ve uygulamalar için de önemli olduğu düşünülmektedir.

$\mathrm{Bu}$ bağlamda yapılan araştırma sonuçlarına göre ülkemizde yaygın olan üniversite öğrencilerinde tutum ve değer yargıları, sosyal gürünüş 
kaygıları sonucu davranışlarını daha olumlu değerlendirmeleri Akılcı Duygusal Davranışçı yaklaşımı temel alan ve değerler eğitimini baz alan eğitim programlarının hazırlanmasına ve alanda ki psikolojik danışmanlara katkı sağlayacağı düşünülmektedir.

\section{Yöntem}

Bu bölümde araştırma modeli, çalışma evreni ve grubu, veri toplama araçları ve verilerin analizinden bahsedilecektir.

\section{Araştırmanın Modeli}

Araştırmada genel tarama modelinin bir alt türü olan ilişkisel tarama modeli kullanılmıştır. İlişkisel tarama, iki ya da daha fazla değişken arasındaki ilişkiyi belirlemek ve neden-sonuç ile ilgili ipuçları elde etmek amacıyla yapılan araştırma modelidir (Büyüköztürk, Kılıç-Çakmak, Akgün, Karadeniz ve Demirel, 2008).

\section{Çalışma Evreni ve Grubu}

Araştırmanın çalışma grubu, 2017-2018 Eğitim-Öğretim yılında İstanbul ilinde yer alan farklı üniversitelerde ve fakültelerde olmak üzere farklı sinıf seviyelerinde eğitim görmekte olan üniversite öğrencilerinin oluşturduğu çalışma grubunun, 327' si kız, 217'si erkek öğrenciden oluşmaktadır. Araştırmaya toplam 544 üniversite öğrencisi katılmıştır.

\section{Veri Toplama Araçları}

Bu araştırmada veri toplama aracı olarak Değerler Ölçeği, Akılcı Olmayan İnançlar Ölçeği ve Sosyal Görünüş Kaygısı Ölçeği Kullanılmıştır. Ayrıca katılımcıların demografik özelliklerini belirlemek amacıyla kişisel bilgi formu kullanılmıştır. Araştırmada kullanılan veri toplama araçları hakkındaki tanıtıcı bilgiler aşağıda verilmiştir. 


\section{Kişisel Bilgi Formu}

Katılımcıların yaş, cinsiyet, sınıf düzeyleri, anne ve babanın eğitim durumu hakkındaki bilgileri toplamak amacıyla araştırmacı tarafindan hazırlanan kişisel bilgi formu kullanılmıştır.

Değerler Ölçeği: Dilmaç, Arıcak ve Cesur (2014) tarafından geliştirilen değerler ölçeği, değer ifadelerinin kişinin yaşamındaki anlam ve önemine göre duygu ve düşüncelerini en iyi yansıttığını düşündüğü değer ifadelerini puanlamaya dayanmaktadır. Ölçek 39 değer ifadesi ve 9 alt boyuttan oluşmaktadır. Değerler (Social Values), ikinci faktör "Kariyer Değerleri (Career Values)", üçüncü faktör "Entellektüel Değerler (Intellectual Values)", dördüncü faktör "Maneviyat (Spritual Values)", beşinci faktör "Materyalistik Değerler (Materialistic Values)", altıncı faktör "İnsan Onuru (Honor of Humanity)", yedinci faktör "Romantik Değerler (Romantic Values), sekizinci faktör "Özgürlük (Freedom)" ve dokuzuncu değer de "Fütüvvet (Futuwwat/munificience\&courage)" olarak isimlendirilmiştir. Ölçek likert tipi olup 0'dan 9'a kadar değer almaktadır. Ölçekten alınan puanın düşmesi ve sıfıra yaklaşması o değerin kişinin yaşamında çok önemli yer tutmadığını; puanın yükselmesi ve dokuza yaklaşması, o değerin kişinin hayatında çok önemli ve vazgeçilmez olduğunu göstermektedir.

Öncelikle tüm değer ifadeleri için temel bileşenler analizi bağlamında açımlayıcı faktör analizi gerçekleştirilmiştir. Kaiser-Meyer-Olkin örneklem uygunluğu değeri .926 ve Bartlett Sphericity Testi yaklaşık KiKare değeri 14543.11 ( $p<.001$ ) olarak bulunmuştur. Bileşen matrisi ve Varimax yöntemiyle gerçekleştirilen döndürme bileşen matrisi incelendiğinde tüm değerlerin toplam varyansın \%65.37'sini açklayan 13 faktör altında toplandıkları görülmüştür. Ortak varyansların "zaman" dişında (.431) tamamının .50'nin üzerinde olduğu tespit edilmiştir. Bununla birlikte döndürülmüş bileşen matrisinde yer alan 14 değerin aynı anda birden fazla faktör altında .10'dan daha düşük bir farkla .32 ve üzeri yük değerine sahip olduğu ya da bir faktör altında tek başına kaldığı görülmüştür (Aile, Zaman ve Kişisel İç Bütünlük tek kalan değerlerdir). Bu nedenle bu 14 değer çıkartılarak aynı koşullar altında benzer nedenlerle açımlayıcı faktör analizi iki kez daha tekrarlanmıştır. Üçüncü faktör analizinde beş 
değer ve dördüncü faktör analizinde ise iki değer daha çıartılmış, geriye kalan 39 değerin sorunsuz bir şekilde toplam varyansın \%64.74'ünü açıklayacak şekilde dokuz faktör altında toplandığı görülmüştür. Son faktör analizinde Kaiser-Meyer-Olkin örneklem uygunluğu değeri .910 ve Bartlett Sphericity Testi yaklaşık Ki-Kare değeri 9133.26 (p<.001) olarak bulunmuştur. Adalet/Hakkaniyet (.466) dişındaki tüm değerlerin ortak varyansını .50 ile .80 arasında değişmekte olduğu görülmüştür.

Değerler Ölçeğinin faktörler bazında Cronbach alfa iç tutarlılık güvenirlik katsayıları da hesaplanmıştır. Analiz sonucunda "Toplumsal Değerler" için .90, "Kariyer Değerleri" için .80, "Entellektüel Değerler" için .78, "Maneviyat"için .81, "Materyalistik Değerler" için .78, "İnsan Onuru" için .61, "Romantik Değerler"için .66, "Özgürlük" için .65 ve "Fütüvvet" için de .63 olarak hesaplanmıştır. Sonuç olarak, Değerler Ölçeği'nin ilk psikometrik bulguları, ölçeğin geçerli ve güvenilir bir ölçme aracı olduğu yönündedir (Dilmaç, Arıcak ve Cesur, 2014).

Akılcı Olmayan Ínançlar Ölçeği: Akılcı olmayan inanç ölçeği Türküm (2003) tarafından geliştirilmiş ve geliştirilme amacı , kişinin akılcı olmayan inanç örüntülerini maddelere dönüştürülerek ele alınmasıdır.Ayrıca Türküm (2003) yurt dışında geliştirilmiş bir ölçeğin Türkçe'ye uyarlanması yerine kültürel faktörleri de titizlikle ele alan bir ölçek geliştirmiştir. Akılcı olmayan inanç ölçeği ilk oluşturulduğunda 29 maddeden oluşmaktaydı fakat daha sonra kısaltma çalışmaları yapılarak 15 madde şeklinde azaltılmıştır. Akılcı olmayan inançlar ölçeği 15 maddeden oluşmakta ve cevaplama şekli :Tamamen Uygun (5), Oldukça Uygun (4), Kararsızım (3), Biraz Uygun (2) ve Hiç Uygun Değil (1) olarak beşli Likert formatı şeklindedir. Ölçekte tersinden puanlanacak madde yoktur. Ölçekten alınabilecek en düşük puan 15, en yüksek puan $75^{\prime}$ dir. Ölçekten alınan yüksek puan akılcı olmayan inanç düzeyinin yüksek olduğuna işaret etmektedir.

Akılcı olmayan inanç ölçeğinin güvenirliliği iç tutarlılık katsayısı ve test-tekrar-test güvenirlilik katsayısı hesaplanarak ele alınmıştır (Türküm, 2003). Bu şekilde Türküm tarafından hazırlanan ölçeğin madde- ölçek korelasyonları.50 ile.52 arasında olup ölçek bütünü için bulunan iç tutarlılık 
katsayısı.75 olarak saptanmıştır. Ayrıca on hafta arayla testin tekrarı yöntemiyle edilen güvenirlilik katsayısı.81 ( $\mathrm{p}<.0001)$ olarak bulunmuştur (Türküm, 2003).

Akılcı olmayan inanç ölçeğinin geçerliliğini denemek için, faktör analiziyle yapı geçerliliği, inanç, sınav kaygısı ve depresyon ölçeklerinden yararlanılarak üç hali hazır geçerlilik çalışması yapılmıştır. Ölçek örneklemde var olan öğrenci gruplarına yapılmış ve elde edilen sonuçlara temel bileşenler analizi ve varimax rotasyon tekniği uygulanmıştır. Varimax rotasyonunda faktör yükü $.40^{\prime}$ in üzerinde olan maddelerin faktörlere dağılması sağlanmıştır. Faktör analizi sonucu bir maddenin kabul edilebilmesi için, o faktördeki yükünün en az 40 olması ve başka faktörde .20'nin üzerinde bir faktör yükü taşımıyor olması kıstas olarak ele alınmıştır. Faktör analizi sonucunda çok sayıda faktör ortaya çıkması hâlinde Scree testi uygulanarak faktör sayısının azaltılması önerilmesi uygun olmaktadır. Akılcı olmayan inanç ölçeği için uygulanan Scree testi sonucunda ulaşılan grafiğe göre, grafik eğrisinin eğimindeki ilk ani fark üçüncü faktörde görülmüştür. Scree test verilerine göre maddelerin üç faktörde toplanması yönünde varimax rotasyonu uygulanmış ve muameleye alınan 29 maddeden 15' inin yukarıdaki ölçütleri yansıttı̆̆ incelenmiştir. Ölçekte tüm faktörler toplam varyansın \% $42.9^{\prime}$ unu ifade etmiş ve bu boyuttaki bulgular; geliştirilen Akılcı olmayan inanç ölçeği ve SKE' den alınan puanlar arasındaki korelasyonun -.03, BDE ile .16 ve bir başka inanç ölçeği olan FOTÖ ile .40 olduğunu saptamaktadır (Türküm, 2003).

Sosyal Görünüş Kaygısı Ölçeği: Sosyal Görünüş Kaygısı Ölçeği (SGKÖ), bireylerin sosyal görünüş kaygilarını ölçmek amacıyla Hart ve arkadaşları (2008) tarafından geliştirilmiştir. Bu çalışmanın amacı, Sosyal Görünüş Kaygıs Ölçeği Türkçe formunun geçerlik ve güvenirliğini incelemektir. Araştırmaya 340 üniversite öğrencisi (143 kız, 197) erkek) katılmıştır. Ölçüt geçerliliğini sınamak amacıyla Olumsuz Değerlendirilme Korkusu Ölçeği Kısa Formu (ODKÖ) kullanılmıştır. SGKÖ’ nün faktör yapısını ortaya koymak üzere açımlayıcı ve doğrulayıcı faktör analizi yapılmıştır. Faktör analizi sonuçları ölçeğin özgün formunda olduğu gibi tek boyutlu bir yapıda olduğunu ortaya koymuştur. SGKÖ için Cronbach alpha iç tutarlık katsayısı .93, testtekrar-test güvenirlik katsayısı .85 ve test 
yarılama yöntemiyle hesaplanan güvenirlik katsayısı .88 olarak bulunmuştur. Ölçeğin Türkçe formunun madde-toplam korelasyon katsayılarının .32 ile .82 arasında olduğu sonucuna ulaşılmıştır. SGKÖ ile ODKÖ arasında .60 ilişki olduğu saptanmıştır. Analizler, SGKÖ' nün Türk üniversite öğrencileri üzerinde yeterli düzeydegeçerlilik ve güvenilirlik değerlerine sahip olduğunu göstermiştir (Doğan, 2010).

\section{Verilerin Analizi}

Araştırmada, üniversite öğrencilerinin sahip olduğu değerlerin, akılc1 olmayan inançlar ve sosyal görünüş kaygıları üzerindeki doğrudan etkisini saptamak için yapısal eşitlik modellemesi analizi yapılmıştır. Yapısal eşitlik modellemesi bir kuramsal modeli test etmek için gözlenen ve gizil değişkenler arasındaki nedensel ve karşılıklı ilişkileri açığa çıkartan istatistiksel bir yaklaşımdır (Shumacker ve Lomax, 2004). Yapısal eşitlik modellemesi analizi AMOS 19 Programı ile ortaya konmuştur.

\section{Bulgular}

Elde edilen son modelde $\left(\mathrm{X}^{2}=\mathrm{X} 2 / \mathrm{sd}=232,847, \mathrm{df}=58, \mathrm{p}<.001\right)$ on exogenus , (toplumsal, kariyer, entelektüel, maneviyat, materyalistlik, insan onuru, romantik, özgürlük, fütüvvet) iki endogenous (sosyal görünüş kaygısı ve akılcı olmayan inanç) veri yer almaktadır. Modelde gösterilen yolların her biri istatistiksel olarak anlamlı bulunmuştur. The Bentler-Bonett normed fit index (NFI), The Tucker-Lewisco efficient fit index (TLI) ve diğer uyum indeksleri modelin oldukça iyi uyumlu olduğunu göstermiştir (Tablo 1). Modelde yer alan endogenous verileri arasındaki iki yönlü korelasyonların her biri yüksek değerlere sahiptir ve istatistiksel olarak anlamlıdır. Bu durum, çalışmada kullanılan değerler ölçeğinin sahip olduğu korelasyon değerlerinden de etkilenmektedir. 


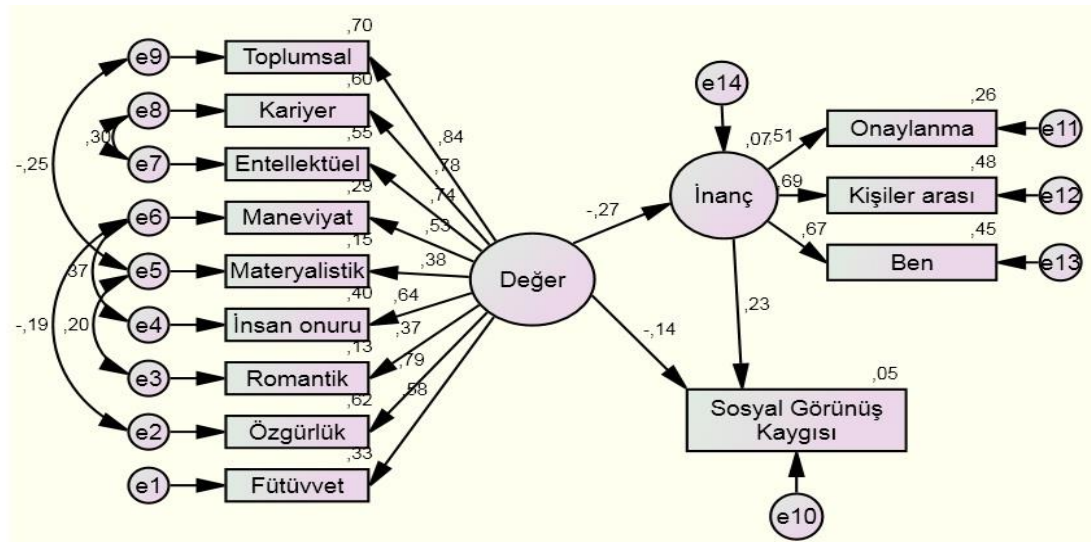

Şekil 1. Modele İlişkin Yol Analizi

Tablo 1. Yapısal Eşitlik Modelinin Uyumuna İlişkin İstatistiksel Değerler

\begin{tabular}{lllc}
\hline Ölçüm & İyi Uyum & Kabul Edilebilir Uyum & $\begin{array}{l}\text { Modelin Uyum } \\
\text { İndeksi Değerleri }\end{array}$ \\
\hline (X2/sd) & $\leq 3$ & $\leq 4-5$ & 4.01 \\
RMSEA & $\leq 0.05$ & $0.06-0.08$ & 0.07 \\
SRMR & $\leq 0.05$ & $0.06-0.08$ & 0.05 \\
NFI & $\geq 0.95$ & $0.94-0.90$ & 0.91 \\
CFI & $\geq 0.97$ & $\geq 0.95$ & 0.95 \\
GFI & $\geq 0.90$ & $0.89-0.85$ & 0.93 \\
AGFI & $\geq 0.90$ & $0.89-0.85$ & 0.89 \\
TLI & $\geq 0.95$ & $0.94-0.90$ & 0.90 \\
\hline
\end{tabular}

Tablo 1'de yer alan uyum değerleri incelendiğinde, $\mathrm{X}^{2} / \mathrm{sd}=4.01$, RMSEA $=0.07, \mathrm{SRMR}=0.05, \mathrm{NFI}=0.91, \mathrm{CFI}=0.95, \mathrm{GFI}=0.93, \mathrm{AGFI}=0.89$ ve TLI $=0.90$, olarak bulunmuştur. Genel olarak, modelin istenen düzeyde uyum değerlerine sahip olduğu anlaşılmaktadır (Bollen, 1989; Browne ve Cudeck, 1993; Byrne, 2010; Hu ve Bentler, 1999; Kline, 2011; Tanaka ve Huba, 1985). Test edilen tek faktörlü model Şekil 1'de gösterilmiştir. Modelde gösterilen tüm yollar 0.001 düzeyinde anlamlıdır. 
Tablo 2. Üniversite Öğrencilerinin Sahip Oldukları Değerler, Sosyal Görünüş Kaygısı ve Akılcı Olmayan İnançlar Arasındaki Yordayıcı İlişkiler

\begin{tabular}{|c|c|c|c|c|c|c|}
\hline $\begin{array}{l}\text { Yordayıcı } \\
\text { Değişken }\end{array}$ & $\begin{array}{l}\text { Bağımlı } \\
\text { Değişken }\end{array}$ & $\begin{array}{l}\text { Toplam } \\
\text { Etki }\end{array}$ & $\begin{array}{l}\text { Doğru- } \\
\text { dan Etki }\end{array}$ & $\begin{array}{l}\text { Dolaylı } \\
\text { Etki }\end{array}$ & $\begin{array}{l}\text { Standart } \\
\text { Hata }\end{array}$ & $\begin{array}{l}\text { Kritik } \\
\text { Değer }\end{array}$ \\
\hline Değer & $\begin{array}{l}\text { Akılcı } \\
\text { Olmayan } \\
\text { İnanç } \\
\end{array}$ & -.27 & -.27 & 0 & 0.07 & $-4.40^{*}$ \\
\hline Değer & $\begin{array}{l}\text { Sosyal } \\
\text { Görünüş } \\
\text { Kaygısı }\end{array}$ & -.15 & -.14 & -.006 & 0.38 & $-2.82^{*}$ \\
\hline $\begin{array}{l}\text { Akılcı Olma- } \\
\text { yan İnanç }\end{array}$ & $\begin{array}{l}\text { Sosyal } \\
\text { Görünüş } \\
\text { Kaygis1 }\end{array}$ & .23 & .23 & 0 & 0.40 & $3.92^{*}$ \\
\hline
\end{tabular}

Şekildeki model incelendiğinde, akılcı olmayan inançları etkileyen önemli bağımsız değişkenin $(t=-4.40, p<0.05)$ değerler olduğu görülmektedir. Bu faktöre ilişkin bağlantı katsayı değeri $\beta=-0.27$ olarak bulunmuştur. Üniversite öğrencilerinin sahip oldukları değerler ile akılcı olmayan inançlar arasındaki yordayıcı ilişkileri incelendiğinde, negatif yönlü doğrusal bir ilişki olduğu belirlenmiştir. Başka bir ifadeyle elde edilen bulgular, üniversite öğrencilerinin sahip olduğu değerlerin artmasıyla, akılcı olmayan inançlarınazalacağını ortaya koymaktadır.

Modelde sosyal görünüş kaygısını etkileyen diğer bağımsız değişkenin $(t=-2.82, p<0.05)$ değerler olduğu görülmektedir. Bu faktöre ilişkin bağlantı katsayı değeri $\beta=-0.15$ olarak bulunmuştur. Üniversite öğrencilerinin sahip oldukları değerler ile sosyal görünüş kaygısı arasındaki yordayıcı ilişkileri incelendiğinde, negatif yönlü doğrusal bir ilişki olduğu belirlenmiştir. Başka bir ifadeyle elde edilen bulgular, üniversite öğrencilerinin sahip olduğu değerlerin artmasıyla, sosyal görünüş kaygılarının azalacağını ortaya koymaktadır.

Modelde sosyal görünüş kaygısını etkileyen önemli bağımsız değişkenin $(t=3.92, p<0.05)$ akılcı olmayan inançlar olduğu görülmektedir. Bu faktöre ilişkin bağlantı katsayı değeri $\beta=0.23$ olarak bulunmuştur. Üniversite öğrencilerinin akılcı olmayan inançlar ile sosyal görünüş kaygısı arasındaki yordayıcı ilişkileri incelendiğinde, pozitif yönlü 
doğrusal bir ilişki olduğu belirlenmiştir. Başka bir ifadeyle elde edilen bulgular, Üniversite öğrencilerinin akılcı olmayan inançlarının artmasıyla, sosyal görünüş kaygılarının artacağını ortaya koymaktadır.

\section{Sonuç}

1. Yapılan araştırma modelinde sosyal görünüş kaygısını etkileyen önemli bağımsız değişkenin değerler olduğu görülmektedir. Bununla birlikte üniversite öğrencilerinin sosyal görünüş kaygısı ile sahip oldukları değerler arasındaki yordayıcı ilişkilere gözlemlendiğinde ise negatif yönlü doğrusal bir ilişki bulgulanmıştır. Yani elde edilen bulgular 1şığında, üniversite öğrencilerinin sahip olduğu değerlerin düzeyinin artış göstermesiyle, sosyal görünüş kaygılarının azalış göstereceğibelirlenmiştir.

2. Yapılan araştırma modelinde sosyal görünüş kaygısını etkileyen önemli bağımsız değişkenin akılcı olmayan inançlar olduğu ortaya çıkmıştır. Bununla birlikte üniversite öğrencilerinin akılcı olmayan inançlar ile sosyal görünüş kaygısı arasındaki yordayıcı ilişkileri ele alındığında, pozitif yönlü doğrusal bir ilişki görüldüğü tespit edilmiştir. Elde edilen bulgular 1şığında, Üniversite öğrencilerinin akılcı olmayan inançlarının artmasıyla, sosyal görünüş kaygılarının artacağını ortaya koymaktadır.

3. Yapılan araştırma modelinde değerlerin akılcı olmayan inançları etkileyen önemli bağımsız değişkenin değerler olduğu görülmektedir. Bununla birlikte üniversite öğrencilerinin sahip oldukları değerler ile akılcı olmayan inançlar arasındaki yordayıcı ilişkileri incelendiğinde, negatif yönlü doğrusal bir ilişki olduğu tespit edilmiştir. Başka bir ifadeyle elde edilen bulgular, üniversite öğrencilerinin sahip olduğu değerlerin artmasıyla, akılcı olmayan inançların azalacağı anlamına gelir.

\section{Tartışma}

Bu bölümde araştırmanın çalışma grubunu oluşturan üniversite öğrencilerinin sahip oldukları değerler, akılcı olmayan inançlar ve sosyal görünüş kaygısı arasındaki yordayıcı ilişkilerin araştırılması sonucu elde edilen 
bulgular tartışılmış ve yorumlanmıştır. Bu hususta, alandaki literatür çalışmaları incelendiğinde hem konu hem de veri toplama kaynakları açısından sınırlı sayıda çalışmaya rastlanmıştır.

Yapılan çalışmada üniversite öğrencilerinin sosyal görünüş kaygısı ile sahip olduğu değerler arasındaki yordayıcı ilişki ele alındığında ise negatif yönlü doğrusal bir ilişki görüldüğü saptanmıştır. Farklı bir dille ele alacak olursak araştırmadan çıkan bulgular, üniversite öğrencilerinin sahip olduğu değerlerde artış göstermesiyle, öğrencilerin sosyal görünüş kaygılarında azalma görüldüğüsaptanmaktadır. Değerlerin sosyal görünüş kaygısını nasıl yordadığı ile ilgili literatür incelendiğinde sosyal görünüş kaygısı kavramı üzerine yapılan çalışma ve incelemelerin oldukça sinırlı olduğu gözlemlenmektedir. Bu yüzden literatürde benzer araştırmalar incelenmiştir. Seki ve Dilmaç (2015) Araştırmalarını 13-18 yaş arası 600 lise öğrencisi ile gerçekleştirmişlerdir. Ergenlerle yaptıkları çalışmada ergenlerin değerler ile öznel iyi oluş ve sosyal görünüş kaygısı seviyelerindeki ilişkiyi araştırmışlardır. Yapılan çalışma sonucuna göre; lise öğrencilerinin sahip olduğu değer değişkeninin sosyal görünüş kaygısı ve öznel iyi oluş değişkeni faktöründe mühim bir etkiye neden olduğutespit edilmiştir. Ergenlerle yapılan çalışmada Seki ve Dilmaç (2015) çalışma verileri sonucunda negatif yönlü doğrusal bir ilişki görüldügü tespit edilmiştir. Bu durumda ele alınan çalışma ile benzer sonuçlara ulaşıldığı görülmüştür.Bunun yanında sosyal görünüş kaygısının beden algısı, sosyal kaygıyı ele alan ve değişkenleri yordayan (Hart diğ., 2008; Levinson ve Rodebauggh, 2011) bir biçimde görülmesi nedeniyle bu araştırmaları destekleyen araştırmalara bakılmıştır. Başka araştırmalara bakıldığında Kashdan ve Roberts (2004) ele aldığı incelemede sosyal kaygı seviyesi etkili olan bireylerin olumsuz hislerinin daha fazla etki gösterdiği tespit edilmiştir. Böylece sosyal görünüş kaygısı ile negatif yönlü bir ilişkinin ortaya çıkması yapılan araştırmalar ile elde ettiğimiz bulguları destekleyici nitelikte olduğu söylenebilmektedir.

Ele alınan modelde sosyal görünüş kaygısı değişkenine etki eden önemli bağımsız değişkenin akılcı olmayan inançlar olduğu ortaya çıkmıştır. Üniversite öğrencilerinin akılcı olmayan inançlar ile sosyal görünüş kaygısı arasındaki yordayıcı ilişkileri ele alındığında, pozitif yönlü doğrusal bir ilişki görüldüğü tespit edilmiştir. Başka bir şekilde dile 
getirildiğinde elde edilen bulgular, Üniversite öğrencilerinin akılcı olmayan inançlarının artmasıyla, sosyal görünüş kaygılarının artacağını ortaya koymaktadır. Literatür incelendiğinde üniversite öğrencilerinin akılcı olmayan inançları ve sosyal görünüş kaygısı arasındaki yordayıcı ilişkilere bakıldığında sınırlı sayıda araştırmaya rastlanmıştır. Bu nedenle sosyal görünüş kaygısı ile akılcı olmayan inançlar ile ilgili benzer araştırmalara bakılmıya çalışılmıştır . Ayrıca akılcı olmayan inançların ve sosyal görünüş kaygısının ruh sağlığını etkileyen çeşitli değişkenlerle ilişkisi görülmekte ve yapılan çalışmayla örtüşmekte olan araştırmalara bakılmaktadır. Gül (2016)' nın yaptığı araştırmada ergenlerin sosyal görünüş kaygısı ve sosyal karşılaştırmanın fonksiyonel olmayan tutum ve bilişsel çarpıtmalarla ilişkisini araştırmış ve elde ettiği sonuç ise ergenlerin fonksiyonel olmayan tutumları ve bilişsel çarpitmaları arttıkça sosyal görünüş kaygısı seviyeleri de bu şekilde yükselmektedir. Gül (2016)' nın ele aldığı araştırma yaptığımız çalışma ile örtüşmektedir. Hart vd. ,(1989) Sosyal görünüş kaygısını, sosyal kaygının bir çeşidi olarak ele alan ve bireylerin fiziksel görünüşlerinin diğerleri tarafından değerlendirilmesinden duyulan kaygı olarak tanımlandırmaktadır. Davison ve Zighelboim (1987) tarafindan yapılan araştırmada deney ve kontrol grubu oluşturularak deney gurubundan 8 üniversite öğrencisi ve kontrol grubunda 15 üniversite öğrencisi ile bu çalışma gerçekleşmiş olup araştırma sonucu verilerine göre akılcı olmayan inançlar ile sosyal kaygı arasında anlamlı bir ilişki bulunmuştur. Ayrıca Kamae ve Weisani (2014), 235 üniversite öğrencisinin katılımıyla gerçekleşen çalışmada sosyal kaygı ile akılcı olmayan inançlar arasındaki ilişkinin anlamlı bir şekilde sonuçlandığı tespit edilmiştir. Bu durumda yapılan araştırmada elde ettiğimiz bulgularla desteklemektedir. Bir başka araştırmada Kashdan ve Roberts (2004) sosyal kayg1, sosyal yetkinlik beklentisi, bireylerin pozitif ve negatif hisleriarasındaki ilişkiyi ele ele aldıkları araştırmada sosyal kaygıları yüksek olan bireylerin negatif duygularının daha yüksek olduğunu dile getirmektedirler. Elde edilen bulgulardan yola çıkarak sosyal görünüş kaygısı ile akılcı olmayan inançlar arasında pozitif yönlü doğrusal bir ilişki olduğu tespit edilmiş olup elde ettiğimiz bulguları destekleyici nitelikte olduğu söylenebilmektedir. Akılcı olmayan inançlar genelde gerçeklikten uzak, şartsız ve mutlak şekilde açılanır ters duygulara yol açar, genelde de bireylerin amaçlarına ulaşmasına mani olur ve bireyin 
kendini kötü hissetmesine sebep olmaktadır (Türkçapar, 2014). Bu bağlamda ise kendini kötü hisseden birey anksiyete ve depresyon gibi birçok psikolojik sorunlar yaşayabilmektedir. Bu yönden Özcan ve Arkadaşları (2013) yaptıkları araştırmada genç yetişkinlik ve ergenlik dönemindeki kadınlarda depresyon, sosyal görünüş kaygısı, anksiyete ve benlik saygısı anksiyete arasındaki ilişkiyi araştırmıştır. Araştırmayı 12-24 yaş arasındaki 176 kadın ile yürütmüşler ve yaptıkları çalışma sonucuna göre; benlik saygısı, sosyal görünüş kaygısı, depresyon ve anksiyete birbirleriyle yüksek seviyede ilişkili oldukları görülmüş ve elde edilen bulguların literatürle destekleyici şekilde olduğu görülmektedir. Tüm bu veriler değerlendirildiğinde üniversite öğrencilerinin akılcı olmayan inançları ile sosyal görünüş kaygıları arasındaki yordayıcı ilişkilerin ele alındığı çalışmaların sınırlı olduğu ve bu çalışmadan elde edilen sonuçların söz konusu değişkenlerin yordayıcılığı olarak yeni bir ışık tuttuğu düşünülmektedir.

Üniversite öğrencilerinin sahip oldukları değerler ile akılcı olmayan inançlar arasındaki yordayıcı ilişkileri incelendiğinde, negatif yönlü doğrusal bir ilişki olduğu belirlenmiştir. Başka bir ifadeyle elde edilen bulgular, üniversite öğrencilerinin sahip olduğu değerlerin artmasıyla, akılcı olmayan inançların azalacağını söylemektedir. Bunun yanında literatürde değerlerin ruh sağlığı ile ilgili birçok değişkenler ile ilişkisi ve akılcı olmayan inançların türlü değişkenlerle ilişkisi ayrı ayrı olarak araştırılmış ve benzer sonuçların ortaya çıtığı görülmüştür.İnsani değerlerin Tanrıseven ve Dilmaç (2013) ile yaptığı araştırmada Araştırmadan çıkan sonuçlara göre ortaöğretim öğrencilerinin sahip oldukları değerler öğrencilerin motivasyon ve öğrenmesinde tesirli bir değişken olduğu ortaya çıkmıştır.Yapılan bir diğer araştırmada Yıldız, Dilmaç ve Deniz (2013) benlik saygısı gibi ile olumlu değişkenlerle arasında pozitif yönde anlamlı bir ilişkinin olduğu görülmektedir. Aynı şekilde akılcı olmayan inançların negatif duygulara ve dolayısıyla depresyona yol açtığı ile ilgili gerçekleştirilen birçok sayıda araştırma bulunmaktadır. Koç (1997), ele aldığı araştırmada akılcı duygusal davranışçı terapinin üniversite öğrencilerinin kendini kabul düzeyleri üzerindeki etkisini çalışmıştır ve araştırma sonucunda akılcı duygusal davranışçı terapinin yaklaşımına dayalı grupla psikolojik danışmanın bireylerin kendini kabul düzeylerine olumlu anlamda etki bıraktığı bulunmuştur. Başka bir araştırmada 
Küçük, Gür, Şener, Boyacıoğlu ve Çetindağ (2016), yaptıkları araştırmada depresyon ve irrasyonel inançların ilişkisini araştırmış ve araştırma sonucunda mantıkdışı inançların bilişsel kuram ve terapide belirleyici bir rol aldığ1 ve depresyon ile ilişkisi olduğu ortaya çıkmıştır. Gökçakan (1997), yaptığı betimsel ve deneysel araştırmada Yapılan Beck'in grupla ve bireysel terapi üniversite öğrencilerinde depresyon düzeyinin azalmasında etkili olduğu belirlenmiştir. Bilişsel davranışçı terapinin ortaya çıkması ilebirlikteyalnızca yurt dışında 1500 'den fazla araştırmada fonksiyonel olmayan tutumların çeşitli hayati olayları nasıl açıkladığı araştırılmış ve fonksiyonel olmayan tutumların inanca özel tutumlar olduğu belirlenmiştir (Clark, Beck ve Alford, 1999; Dobson, 2009).Tutumların biçimlenmesinde ve hayatın anlaşılıp yorumlanmasında birer yol gösterici olan değerler ise gücünü inançlardan almaktadır (Arslan, 2006). Bu bağlamda araştırmada da incelendiği gibi değerleri tanımlarken Göngör (1993)'e göre istenebilir yada arzu edilmez olduğu durumundaki inançlarımız olduğunu dile getirmiştir. Yapılan araştırmada incelenen değerlerin insani değerler olduğu belirtilirken bireylerin değer yargıları yükseldikçe akılcı olmayan inançlarının düşmesi, bireyin değer yargılarına verdiği önem arttıkça kişinin yaşamı ve anlamını daha hakiki bir şekilde kavramlaştırabilmesinden; değerlerin inançlara daha engin açıdan bakmasından kaynaklanıyor olabilir. Tüm bu bulgular dolaylı bir şekilde ele alınsa da araştırmada elde edilen model ile anlamlanmakta ve bireyin sahip olduğu değerlerin yüksek olması bireyde pozitif ruh halleri sergilemesine neden olurken, akılcı olmayan inançlarının azalmasına sebep olmaktadır.

Tüm bu incelemeler ışığında yapılan çalışmanın nüfus bakımından genç bir ülke olarak tanımlanan ülkemizde gençlerin ifade edilmesinde üniversite öğrencilerinin tutum ve davranışlarını daha iyi bir şekilde değerlendirilmesine katkı sağlayacağı düşünülmektedir. Benzer çalışmaların alandaki araştırmacılara katkı sağlayacağı ve diğer yaş aralıklarında da uygulanması konuyla alakalı daha boyutlu bilgi edinilmesine etki edeceği düşünülmektedir. 


\section{Öneriler}

1. Bu araştırma üniversite öğrencileri üzerinde yapılmıştır. Fakat benzer bir çalışma farklı yaş grupları veya meslekler ile yapılması da faydalı olabilir.

2. Bu araştırma değerler, akılcı olmayan inançlar ve sosyal görünüş kaygısı arasındaki yordayıcı ilişkiler çalışılmıştır. Başka araştırmalarda benzer çalışmaların cinsiyet, sosyo ekonomik durum, aile eğitim durumu gibi değişkenler açısından araştırılmasının alana katkı sağlayacağı ön görülmektedir.

3. Ruh sağlığını etkileyen akılcı olmayan inançlar ve sosyal görünüş kaygısının değerleri yordadığı için özellikle üniversite gençlerinde değerler eğitimi ile ilgili etkinliklerin ve çalışmaların arttırılması oldukça önemli olduğu düşünülmektedir.

4. Ülkemizde değerler, akılcı olmayan inançlar ve sosyal görünüş kaygısı

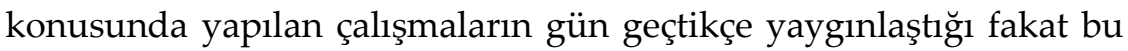
üç değişkenin birbiri ile ilişkisini ortaya koyan çalışmaların sınırlı olduğu düşünülmektedir.Bu konuda yeni araştırmaların birçok bilime ve alanda çalışan psikolojik danışman, psikologlara katkı sağlayacağı düşünülmektedir. 


\section{EXTENDED ABSTRACT}

\section{The Precurser Relations among The Values Which The University Students Have Their Irrational Belief and Their Social Apperance Anxiety \\ $*$

\author{
Bülent Dilmaç - Ömer Yücesoy \\ Necmettim Erbakan University-Ministry of National Education
}

The aim of the research is to study the precurser relation among the values which the university students have, their irrational beliefs and their social apperance anxiety. İ the research, structural equation modeling analysis is carried out with the purpose pf testing the precurser relation among the values, irrational beliefs and social appearance anxiety. The scales are composed of university students from various universities in Istanbul during the 2017-2018 education period. Of the 544 participants, 217 are male and 327 are female par-ticipants. In the research, structural equation modeling analysis is carried out with the purpose pf testing the precurser relation among the values, irrational beliefs and social appearance anxiety. İt is carried out with AMOS 19 program.In this research, we were used the personal information form, The Value Scale, determining yhe values witch the unniversity students have, the irrational beliefs scale determining their irrational beliefs, the social apperance anxiety scale determing their social apperance anxiety.Percentage and freqvency calculation of collecded data were olso perfermed with the SPSS 18 packed program.

In this study, which has a quantitative research paradigm, it is aimed to determine university student's values, irrational beliefs and to determine the relationships between social apperance anxiety and to test the relationships between these variables with structural equation model. For this purpose, the research was carried out according to the relational screening model, which is a sub-type of the general screening model. General screening models are screening studies in order to reach a general judgment about the universe on a group of samples or samples taken from the universe or the universe. General screening models allow individual 
or relational scans (Karasar, 2015). Relational screening models are research models aiming to determine whether or not the change between two or more variables coexists or not (Karasar, 2015).

According to the findings as a result of the study it determined that there is a negative relationship between the values and irrational beliefs. İt has also determined that there is a negative relationship between the values and the social apperance anxienty. Finally, when the precursor relations of the university students irrational beliefs and the social apperance anxiety have studied, it has determined that there is a positive relationship between them.

\section{Discussion ve Conclusion}

1. According to the findings as a result of the analyzes, it determined that there is a negative relationship between the values and irrational beliefs, in other words, whem the values which the university students have increase, their irrational beliefs will decrease.

2. Determined that there is a negative relationship between the values and the social apperance anxienty.In other words, whem the values which the university students have increase, their social apperance anxienty will decrease.

3. Finally, when the precursor relations of the university students irrational beliefs and the social apperance anxiety have studied, it has determined that there is a positive relationship between them. in other words, whem the irrational beliefs which the university students have increase, social appearonce anxiety will increase.

\section{Suggestions}

1. This research was directed by the university students.However, a similar study may be performed with different age groups or different occupations.

2. In this study, predictive relationships between the values, irrational beliefs and social appearance anxiety were studied. İt is envisaged that similar studies in terms of variable such as gender education status and socioeconomic status will contribute to this field. 
3. It is thought that it is very important to increase the activities and activities related to education of values in university youth, especially as it determines the values of irrational beliefs and social appearance that affect mental health.

4. İt is thought that the studies conducted on the values, irrational beliefs and social appearance anxiety in our country are spreading day by day but the studies that reveal the relationship of these three variables with each other are limited.New researches on this subject are thought to contribute psychological counselors and psychologists working in many sciences in the field.

\section{Kaynakça / References}

Akyüz, İ. (2014). Türkiyede gençlik din ve değerler konusunda yapılan ampirik araştırmaların yöntem ve içerik analizi. Sakarya Üniversitesi İlahiyat Fakültesi Dergisi, 16(30), 183-202.

Arnett, J.J. (2006) G. Stanley Hall's adolescence: Brilliance and nonsense. Hist Psychol, 9,186-197.

Arslan, Z. (2006). Öğretmenlerde dindarlık, değerler ve iş doyumu üzerine bir araştırma. Yayımlanmamış Yüksek Lisans Tezi, Ankara Üniversitesi Dil Tarih Coğrafya Fakültesi, Ankara.

Atak, H. Çok, F. (2010). Beliren yetişkinlik (emerging adulthood): İnsan yaşamında yeni bir dönem. Çocuk ve Gençlik Ruh Sağllğı Dergisi,17, 39-50.

Aydın, M. (2003). Gençliğin değer algısı:Konya örneği. Değerler Eğitimi Dergisi, 1 (3), 121-144.

Bilgin, N.(1995). Sosyal psikolojide yöntem ve pratik çalışmalar. İstanbul: Sistem Yayıncilik.

Büyüköztürk, Ş., Kılıç-Çakmak, E., Akgün, Ö. E., Karadeniz, Ş. ve Demirel, F. (2008). Bilimsel araştırma yöntemleri. Ankara: Pegem.

Corey, G. (2008). Psikolojik danışma, psikoterapi kuram ve uygulamaları (T. Ergene, Çev.). Ankara: Mentis Yayıncılık.

Davison, G. C., ve Zighelboim, V. (1987). Irrational beliefs in the articulated thoughts of college students with social anxiety. Journal of Rational-Emotive Therapy, 5(4), 238-254. 
Dilmaç, B., Arıcak, O.T. ve Cesur, S. (2014). A validity and reliability study on the development of the values scale in Turkey. Educational Sciences: Theory \& Practice, 14(5), 1661-1671.

Doğan, S. (1995). Akılcı duygusal terapi: Kuramsal bir inceleme. Psikolojik Danışma ve Rehberlik Dergisi, 2(6), 19-25.

Doğan, T. (2010). Sosyal görünüş kaygısı ölçeği" nin Türkçeye uyarlaması: Geçerlik ve güvenilirlik çalışması. Hacettepe Üniversitesi Eğitim Fakültesi Dergisi, 39, 151-159.

Dobson, K.S. (ed.) (2009). Handbook of cognitive-behavioral therapies. New York:Guilford Press.

Ellis, A. (1995). Current psychotherapies.( R. J. Corsini, D. Wedding Ed.) (5th Ed.). Illinois: F.E. Peacock Publishers, Inc.

Yılmaz-Erdem, A. ve Bilge, F. (2008). Meslek seçimine ilişkin akılcı olmayan inançlar ölçeği:Lise öğrencileri için akılcı olmayan inançlar ölçeğinin geliştirilmesi. Türk Psikolojik Danışma ve Rehberlik Dergisi, 3(29), 95-114.

Gökçakan, N. (1997). Çeşitli derecelerdeki depresyonun giderilmesinde Beck'in bilişsel terapisinin etkinliğinin incelenmesi.Yayınlanmamış Doktora Tezi, K.T.Ü. Sosyal Bilimler Enstitüsü, Trabzon.

Güngör, E. (1993). Değerler psikolojisi. Amsterdam: Hollanda Türk Akademisyenler Birliği Vakfı Yayınları.

Güngör, E. (2010). Değerler psikolojisi üzerine araştırmalar. (4. Bs.). İstanbul: Ötüken Neşriyat.

Gül, E., (2016). Ergenlerde sosyal görünüş kaygısı ve sosyal karşılaştırmanın fonksiyonel olmayan tutum ve bilişsel çarpıtmalarla ilişkisi. Yüksek Lisans Tezi, Üsküdar Üniversitesi, Sosyal Bilimler Enstitüsü, Klinik Psikoloji Anabilim Dalı, İstanbul.

Hart, T. A., Flora, D. B., Palyo, S. A., Fresco, D. M., Holle, C. ve Heimberg, R. G. (2008). Development and examination of the social appearance anxiety scale. Assessment, 15(1), 48-59.

Hart, E. A., Leary, M.R. ve Rejeski, W. J. (1989). The measurement of social physique anxiety. Journal of Sport and Exercise Psychology, 11, 94104.

Hökelekli, H. (2006). Gençlik ve din, gençlik, din ve değerler psikolojisi. (H. Hökelekli, Ed.). İstanbul: Dem. 
Kashdan, T. B. ve Roberts, J. E. (2004). Social anxiety's gmpact on affect, curiosity, and social self-efficacy during a high self-focus social threat situation. Cognitive Therapy and Research, 28(1), 119-141.

Kamae, A. ve Weisani, M.(2014). The relationship between social anxiety irrational beliefs and emotional intelligence with homesickness in dormitory students of Tehran University. Indian Journal of Fundamental and applied Science, 4 (1), 285-292.

Koç, M. (1997). Rasyonel emotif terapinin düşük benlik kabulünü yükseltmedeki etkinliğinin araştırılması. Yayımlanmmaış Doktora Tezi K.T.Ü. Sosyal Bilimler Enstitüsü, Trabzon.

Kulaksızoğlu, A.,ve Dilmaç, B. (2000). İnsani değerler eğitimi programı. Marmara Üniversitesi Atatürk Ĕ̆itim Fakültesi Eğitim Bilimleri Dergisi, 12, 199208.

Kuşdil, M.E. ve Kağıtçıbaşı, Ç. (2000). Türk öğretmenlerinin değer yönelimi ve Schwartz değer kuramı. Türk Psikoloji Dergisi, 15 (45), 59-76.

Leary, M.R. ve Kowalski, R.M. (1995). The self-presentation model of social phobia. (Heimberg, R.G., M.R. Liebowitz, D.A. Hope ve F.R. Schneier Ed.), Social Phobia: Diagnosis, Assessment and Treatment (s.94-112). New York: Guilford Press.

McKinley, N. M. ve Randa, L. A. (2005). Adult attachment and body satisfaction:An exploration of general and specific relationship differences. Body Image, 2(3), 209-218.

Mehmetoğlu, U.(2006). Gençlik, değerler ve din, küreselleşme, ahlak ve değerler. (Ed.Mehmetoğlu \& Mehmetoğlu). İstanbul: Litera Yayıncılık.

Özcan, H., Subaşı, B., Budak, B., Çelik, M., Gürel, Ş., Yıldız, M. (2013). Ergenlik ve genç yetişkinlik dönemindeki kadınlarda benlik sayg1sı, sosyal görünüş kaygısı, depresyon ve anksiyete ilişkisi. Journal of Mood Disorders, 3 (3), 107-113.

Savaşır, I. ve Batur, S. (1996). Bilişsel davranış̧̧ı terapiler:Depresyonun bilişsel davranışçı tedavisi, (I. Savaşır, G. Boyacıoğlu, ve E. Kabakçı Ed.),(2. Bsm.), Ankara: Türk Psikologlar Derneği Yayınları No:7, 
Schwartz, S. H. (1992). Universals in the contend structure of values: Theoritical advences and emprical tests in 20 countries. in Zanna (Ed.) Advances in Experimental Social Psychology (25, 1-65). New York: Academie Pres.

Seki, T., ve Dilmaç, B. (2015). Ergenlerin sahip oldukları değerler ile öznel iyi oluş ve sosyal görünüss kaygı düzeyleri arasındaki yordayıcı ilişkiler, Bir Model Önerisi. Eğitim Ve Bilim, 40 (179), 57-67.

Tanrıseven, I. ve Dilmaç, B. (2013). Orta öğretim öğrencilerinin insani değerleri, motivasyonel inançları ve öz-düzenleme stratejileri arasındaki yordayıcı ilişkiler. Kuram ve Uygulamada Ĕ̆itim Bilimleri, 13(1), 21-36.

Türkçapar, M. H. (2014). Bilişsel terapi. Ankara: Hyb Yayıncılık.

Türküm, A. S. (2003). Akılcı olmayan inançlar ölçeğinin geliştirilmesi ve kısaltılması. Türk Psikolojik Danışma ve Rehberlik Servisi, 2(9), 41-47.

Ulusoy, K. ve Dilmaç, B. (2016). Değerler eğitimi, (4. Bs.) Ankara:Pegem Akademi.

Yıldız, M., Dilmaç, B., ve Deniz, M. E. (2013). Öğretmen adaylarının sahip oldukları değerler ile benlik saygıları arasındaki ilişkinin incelenmesi. İlköğretim Online, 12(3), 740-748.

Yurtal, F. D. (1999). Üniversite öğrencilerinin akılcı olmayan inançlarının bazı değişkenlere göre incelenmesi.Yayımlanmamış Doktora Tezi, Gazi Üniversitesi, Ankara.

\section{Kaynakça Bilgisi / Citation Information}

Dilmaç. B. ve Yücesoy, Ö. (2019). Üniversite öğrencilerinin sahip olduğu değerler akılcı olmayan inançlar ve sosyal görünüş kaygısı arasındaki yordayıcı ilişkiler. OPUS-Uluslararası Toplum Araştırmaları Dergisi, 11(18), 1684-1708. DOI: 10.26466/opus.547765 